\title{
Micropropagated Raspberry Plant Establishment Responds to Weed Control Practice, Row Cover Use, and Fertilizer Placement
}

\author{
David L. Trinka and Marvin P. Pritts \\ Department of Fruit and Vegetable Science, Cornell University, Ithaca, NY 14853
}

Additional index words. tissue culture, Rubus idaeus, herbicide, mulch, polyethylene, polypropylene

\begin{abstract}
Micropropagated (MP) raspberries (Rubus idaeus L. var. idaeus) are sensitive to moisture and temperature extremes and to certain preemergent herbicides used at transplanting. We examined fertilizer placement and row covers in conjunction with various weed management strategies to identify beneficial practices for newly planted, MP primocane-fruiting 'Heritage' raspberries. Uncontrolled weed growth during plant establishment inhibited raspberry cane growth and production into the second and third growing seasons. Handweeding and herbicide treatments successfully controlled weeds, but soil moisture was apparently insufficient for optimum growth of the MP raspberries when these treatments were imposed, even with normal rainfall in early summer and drip irrigation in late summer. Polyethylene and straw mulches during the establishment year provided both weed control and adequate soil moisture, resulting in more cane growth in the first and 2nd year, and higher yields the 2nd year. Primocane density after the third growing season still was influenced by first-year weed management practices. Raspberry plants responded best to straw mulch without row covers as plant growth was better in both years. Canes were thicker, yields were higher, and a larger portion of the total crop was harvested early. Row covers were beneficial only in bare-soil treatments, and method of fertilizer placement had no effect on any measured variable. Mulching newly transplanted MP raspberries is an alternative to herbicide use that also provides physiological benefits to the plant through microclimate modification.
\end{abstract}

Conventionally propagated, dormant suckers have been the standard transplant type used by raspberry and blackberry $(R$. fruticosus L.) growers until the recent availability of nondormant, tissue-cultured plants in soilless plugs. Growers have readily accepted these MP plants because they offer several advantages over conventional transplants, such as uniformity, ease of handling, freedom from known pathogens, and rapid 2nd-year growth. MP plants also can be set with a planter, unlike larger, nonuniform conventional transplants.

Some growers and nursery operators, however, have reported poor MP plant establishment and unsatisfactory growth. Poor performance often can be attributed to environmental sensitivity during establishment, primarily to wind, drought, and low temperatures (Pritts and Handley, 1989). Also, spring-planted raspberries do not tolerate weed competition well (Lawson and Wiseman, 1974, 1976), yet weed control during early plant establishment is problematic because MP raspberries are less tolerant to currently available herbicides and cultivation than are standard transplants, (Meador, 1985; Mudge et al., 1987; Neal et al., 1990). These observations suggest that establishment practices suitable for conventional transplants may have to be modified for successful field establishment of the MP plant.

The objective of our research was to examine establishment practices of mulching, row cover use, and fertilizer placement to determine if any could improve growth and subsequent yield of MP raspberries. Mulching is a possible alternative to cultivation or herbicide use for early season weed control (Childs, 1941; Clark, 1940; Darrow and Magness, 1938; Judkins, 1944),

Received for publication 6 Feb. 1992. Accepted for publication 4 May 1992. Dept. of Fruit and Vegetable Science Paper no. 26. This research was supported through Hatch Project NYS142-402 and through U.S. Dept. of AgricultureCooperative Agreement 92 coop-1-7191. We thank Mary Jo Kelly, Marcia Eames-Sheavly, and Rick Reisinger for their help with data collection and plot maintenance. Ian Merwin and Mary Jo Kelly provided helpful reviews. The cost of publishing this paper was defrayed in part by the payment of page charges. Under postal regulations, this paper therefore must be hereby marked advertisement solely to indicate this fact. but its use on MP plants during establishment has not been tested. Row covers provide frost protection and growth enhancement in certain berry crops (Pollard and Cundari, 1988; Pritts et al., 1989), but row cover use on raspberries has been reported only in established plantings of primocane-fruiting types (Pritts et al., 1992). Method of fertilizer placement has been shown to influence growth of other mechanically transplanted crops (Randall, 1984; Voth and Bringhurst, 1990), but the effect of fertilizer placement in raspberry plantings is unknown.

Our specific objectives were to: 1) identify an effective weed control practice that would not be detrimental to newly set MP propagules, 2) determine if row cover use after planting improves early growth and subsequent yield, and 3) determine if MP plants respond better to $\mathrm{N}$ incorporation in the planting hole, as opposed to surface applications after planting.

\section{Materials and Methods}

Design of experiment. The experiment was located at Cornell Orchards, Ithaca, New York. The soil was a Collamer silt loam (Typic Hapludalf, $\mathrm{pH}=5.2)$. Ground limestone $\left(7.4 \mathrm{t} \cdot \mathrm{ha}^{-1}\right)$ was applied and incorporated the fall before planting to achieve the target $\mathrm{pH}$ of 6.0 . No nutrient additions, except $\mathrm{N}$, were made during the course of the experiment.

'Heritage' was used because it is the most widely grown of the primocane-fruiting raspberries. Green, actively growing, tissue-cultured plants in plugs were planted in late May 1989 after 2 weeks of acclimation outdoors. The transplants had 10 to 15 $\mathrm{cm}$ of succulent top growth and well-developed root systems that completely filled their $4 \mathrm{~cm} \times 4 \mathrm{~cm} \times 5.5-\mathrm{cm}$ containers. All plants were planted by hand. Each experimental unit consisted of seven plants spaced $0.75 \mathrm{~m}$ apart, in rows spaced $3 \mathrm{~m}$ apart.

The experimental treatments were arranged as a fractionally replicated factorial consisting of three factors: weed control,

Abbreviation: MP, micropropagated. 
fertilizer placement, and row cover usage. Seven weed contro strategies were used: 1) Untreated. Weeds were allowed to grow unchecked from the time of planting until late summer of the establishment year, at which time they were cut to ground level. All weedy topgrowth was removed from the treatment area, bu weed roots were left undisturbed. 2) Handweeded. Weeds were removed monthly by pulling and/or shallow hoeing. 3) Napropamide at $2.2 \mathrm{~kg} \cdot \mathrm{ha}^{-1}$ was applied 2 weeks after planting to a $1-\mathrm{m}$ band centered on the plant row. The herbicide was applied with a $\mathrm{CO}_{2}$-powered backpack sprayer. No weeds were present at the time of application. Adequate rainfall occurred shortly after application, ensuring good soil incorporation. One supplemental hand hoeing was done in mid-August to control weed that escaped. 4) Simazine at $1.1 \mathrm{~kg} \cdot \mathrm{ha}^{-1}$ was applied in the same manner and under the same conditions as indicated above for napropamide. One handweeding was done in mid-August 5) Black polyethylene. Sections of a 1.2-m-wide black polyethylene film $(0.03-\mathrm{mm}$ thick) were applied to the appropriate plot immediately before planting. The edges of the film were secured by placing them in a shallow trench and then covering them with soil. The effective width of the mulch surface was $\approx 0.9$ $\mathrm{m}$. Plants were set through slits cut in the film. 6) White-onblack polyethylene. Black polyethylene was applied in the same manner as described above. White latex paint in a 1 paint : 3 water per volume mixture was then sprayed on the surface of the film with a Solo backpack sprayer. 7) Straw mulch. An 8 to 10-cm layer of slightly decomposed wheat straw was applied to the 0.9-m-wide row area shortly after planting. Some settling of the mulch occurred, so additional straw was added in midJuly to maintain the appropriate mulch thickness.

A second factor was row cover treatment. Spunbonded polypropylene covers (Kimberly Farms, Roswell, Ga.; $20 \mathrm{~g} \cdot \mathrm{m}^{-2}$ ) were applied to handweeded, black polyethylene, white-on-black polyethylene, and straw treatments; an equal number remained uncovered. The herbicide-treated and unmanaged plots did not receive a cover. A $1.8-\mathrm{m}$-wide strip of row cover material was placed directly over the raspberries shortly after planting. No support hoops were used. Edges of the row covers were held tightly to the ground surface with soil. Row covers were removed from the covered treatments on 25 July 1989.

A third factor was fertilizer placement. All weed control/row cover treatments received two methods of fertilizer placement Calcium nitrate was applied to supply $30 \mathrm{~kg} \cdot \mathrm{ha}^{-1}$ of $\mathrm{N}$ to eithe the soil surface around the transplant or mixed in the planting hole, $\approx 5-\mathrm{cm}$ beneath the plant roots, at the time of planting.

Treatments were applied in a randomized complete-block design and were replicated three times, for a total of 66 experimental units.

Rainfall was above normal for May and June and normal fo July. No supplemental water was supplied to plants until August, at which time a trickle irrigation system was installed. Irrigation was managed so that the soil water potential in the driest treatments did not exceed $100 \mathrm{kPa}$.

All mulches were removed in late Winter 1990, and canes were cut to ground level before growth began. Standard cultural practices were followed during the 1990 season. Calcium nitrate was broadcast to supply $60 \mathrm{~kg} \cdot \mathrm{ha}^{-1}$ of $\mathrm{N}$ over the row in early spring. Oryzalin at $4.5 \mathrm{~kg} \cdot \mathrm{ha}^{-1}$ was applied to the row area before cane emergence. Supplemental handweeding was done regularly in all plots to maintain an essentially weed-free condition. Weeds in alleys were controlled by mechanical cultivation. All rows were narrowed to $0.7 \mathrm{~m}$ in June and maintained at that width for the remainder of the season. Plants were drip irrigated periodically to supplement natural rainfall, and a temporary trellis system was installed in August to facilitate harvesting and spraying. Plants were managed in an identical fashion during 1991

Measurements of microclimate, vegetative, and reproductive performance. Vegetative growth was measured in 1989 on three representative inner five plants in each seven-plant treatment. Primocane length and node count were measured weekly from 6 July to 18 Sept. These data were collected from the single tallest primocane arising from the original mother plant. Lea transpiration and stomatal conductance measurements (LI-COR, LI-1600 Steady State Porometer, Lincoln, Neb.) were taken several times during the season, both before and after row covers were removed. The middle leaflet arising from the third to fifth node basipetal to the uppermost bud was used for obtaining these measurements.

Environmental measurements were obtained at midday from all plots in two of the three blocks at about weekly intervals. Soil temperature at a $15-\mathrm{cm}$ depth beneath the soil surface was recorded with a thermister probe. Soil moisture at the $15-\mathrm{cm}$ depth was monitored with soil moisture tensiometers. Air temperature at the soil (or mulch) surface was recorded with min/ max thermometers. All thermometers were shielded from direct sun with waxed cardboard containers.

Leaf samples for tissue-nutrient analysis were collected in mid-August and analyzed for all macro- and micronutrients, except S. The weight of dormant canes was recorded for each plot during cane removal in early 1990 . We attempted to quantify root distribution in the plots, but the fibrous nature of raspberry roots made quantification difficult.

Vegetative growth and fruit yield were measured during the 1990 growing season. Data for vegetative growth measurements were obtained from a representative $0.5-\mathrm{m}^{2}$ area within each plot. Primocane length was recorded weekly from 11 May to 3 Aug. and again on 16 Oct. within this plot. Cane length was determined by measuring the tallest primocane within the sampled area. Cane density was recorded monthly during May to August and again on 16 Oct., when the percentage of fruiting canes also was determined. Fruit was harvested every 2 to 4 days from 22 Aug. to 2 Oct. from all canes in the seven-plant plots. The average fruit weight was determined from a 50-berry sample on each of the 15 harvest dates. All canes within the sampled area were pruned to ground level at the end of the season, and the basal diameters of the canes were then measured $3 \mathrm{~cm}$ above soil line.

During the 1991 growing season, all plots received the same standard treatment as described for the previous year. At the end of the third growing season, cane density was measured but yields were not recorded.

Analysis. Analysis of variance (ANOVA) techniques appropriate for the fractional factorial randomized-block design were used to test for differences among factors. Treatment mean separation was based on Fischer's protected least significant difference (LSD)

\section{Results}

\section{Establishment year (1989)}

Effects on raspberry plants. Weed control treatments significantly affected primocane growth during the year of establishment (Table 1). Mulched plants produced longer canes than unmulched plants. Row covers reduced cane length in mulched 
Table 1. Effects of weed-control treatments on first-year growth of 'Heritage' raspberry. Cane length and weights were measured at the end of the growing season; foliar nutrient levels were determined in August.

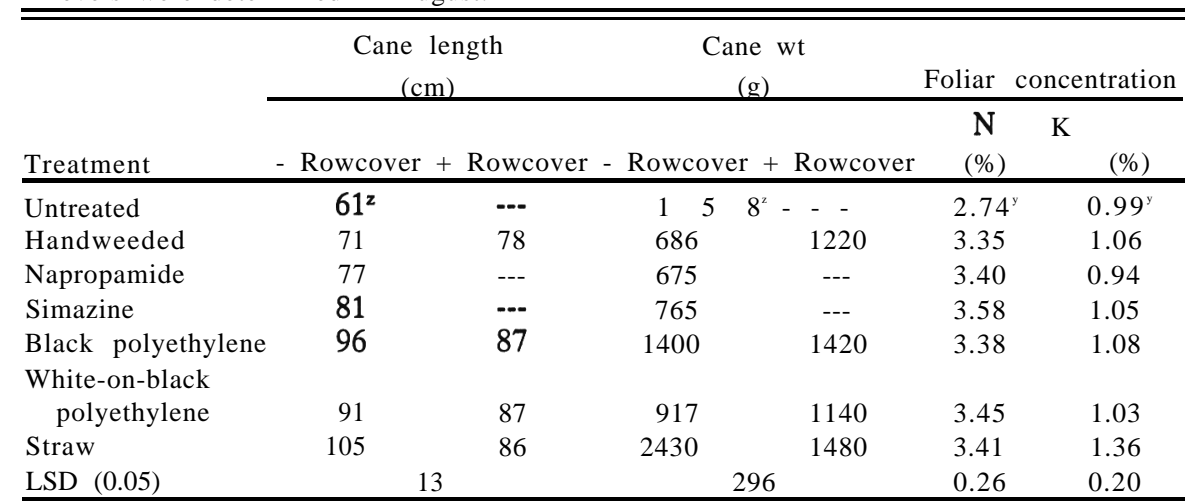

${ }^{2}$ Values are averaged over two fertilizer treatments of three replicates each for a total of six experimental units.

${ }^{y}$ Values for handweeded and mulched plots are averaged over two fertilizer and row cover treatments of three replicates each for a total of 12 experimental units. Herbicide and control treatments represent six experimental units.

treatments, but increased cane length in the bare soil treatment, resulting in a significant interaction. The cane length of plants in most treatments was similar throughout the year, but cane extension of plants in unweeded plots slowed in August due to severe competition from weeds (Fig. 1).

Weed control treatments had a significant effect on the total weight of canes at the end of the season (Table 1). Without row covers, straw mulch and black polyethylene treatments produced significantly higher cane biomass than either herbicidetreated or unweeded plots. Significant interactions occurred between weed control and row covers, reflecting the same pattern as cane length. The use of row covers increased cane weights by $43 \%$ in the handweeded plots and decreased them by $39 \%$ in the straw-mulched plots, when compared to uncovered plots.

Weed control practice influenced the rate at which mature leaves of 'Heritage' transpired. Transpiration rate, expressed as stomal conductance, was higher under row covers (data not shown), and higher in mulched than in herbicide-treated plots (Fig. 2). Simazine-treated plants consistently had the lowest transpiration rates, significantly lower than handweeded plants on 6, 14, and $24 \mathrm{July,} \mathrm{and} \mathrm{significantly} \mathrm{lower} \mathrm{than} \mathrm{napropam-}$ ide-treated plants on two of these dates. Differences in soil

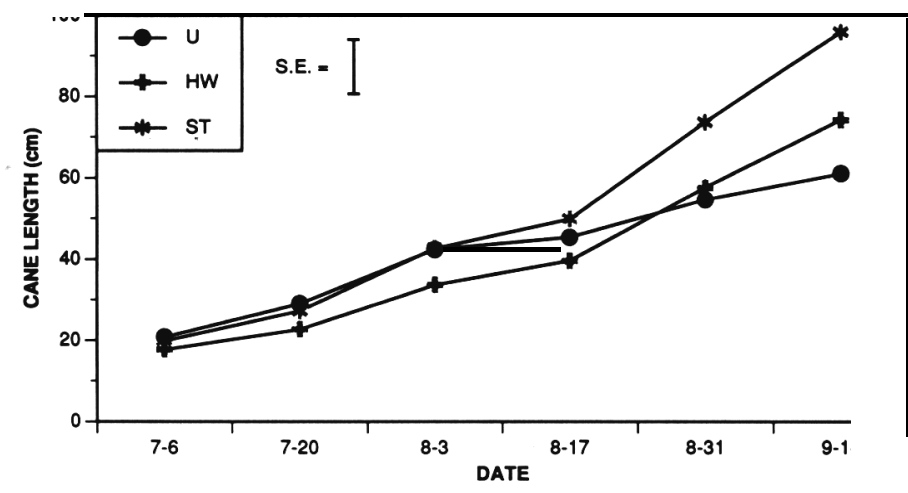

Fig. 1. Growth of 'Heritage' raspberry primocanes in selected weedcontrol treatments during the first growing season (1990). Key to treatments: $\mathrm{U}=$ untreated, $\mathrm{HW}=$ handweeded, and $\mathrm{ST}=$ strawmulched.

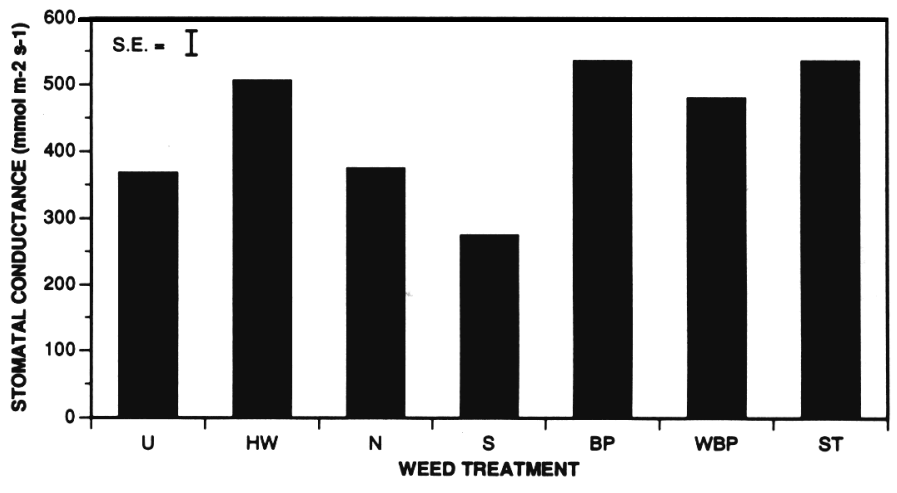

Fig. 2. Influence of weed control treatments on stomata1 conductance of 'Heritage' raspberry on 6 July 1989, when differences in soil moisture among treatments were greatest. Each bar represents the mean of 12 readings. Key to treatments: $\mathrm{U}=$ untreated, $\mathrm{HW}=$ handweeded, $\mathrm{N}=$ napropamide, $\mathrm{S}=$ simazine, $\mathrm{BP}=$ black poly ethylene, $\mathrm{WBP}=$ white-on-black polyethylene, and $\mathrm{ST}=$ straw .

moisture between these three treatments (simazine, napropamide, and handweeded) were not significant on these dates.

Neither fertilizer placement nor row cover use affected foliar nutrient levels for any element. Weed control practice had significant effects on concentrations of $\mathrm{N}$ and $\mathrm{K}$ in leaves, with low $\mathrm{N}$ in untreated plots and high leaf $\mathrm{K}$ in straw-mulched plots (Table 1).

Effects on weeds. The polyethylene covers provided complete control of weeds throughout the establishment year. The straw mulch suppressed most annual and perennial weed species, except yellow nutsedge (Cyperus esculentus L.). At 60 days after herbicide application, simazine-treated plots had fewer weeds than those treated with napropamide. Quackgrass (Agropyron repens Beauv.), broadleaf plantain (Plantago major L.), and dandelion (Taraxacum oficinale Weber.) were the major weeds in both herbicide-treated plots. Unmanaged plots were dominated by these three species, plus common ragweed (Ambrosia artemisiifolia L.), lambsquarters (Chenopodium album L.), redroot pigweed (Amaranthus retroflexus L.), and yellow foxtail (Setaria lutescens Hubb.).

Effects on microclimate. Soil moisture appeared to be ade- 
quate in all plots during June due to higher than average precipitation; however, large differences in soil moisture occurred during July and early August as a result of weed control treatments (Table 2). The mulched plots contained significantly more moisture than any other plots during this period. Row covers had no effect on soil moisture level in the mulched soils, but row covers did reduce moisture loss from the bare, unmulched soil in the handweeded treatment.

Weed control and row cover treatments significantly affected early season soil temperatures (Table 2). They were consistently the highest under the black polyethylene, followed by simazine, white-on-black polyethylene, and handweeded. Soil temperatures were lowest under the straw mulch. Significant weed control $\times$ row cover interactions were also observed. Soil temperatures were higher in the covered handweeded, whiteon-black polyethylene, and straw-covered plots than in uncovered plots, but differences between covered and uncovered were not significant for black polyethylene. By October, differences in soil temperatures were negligible $(X=13.8, \mathrm{SE}=0.15)$.

Minimum and maximum air temperatures were influenced by weed control treatments and the use of row covers during the early portion of the establishment year (Fig. 3). Mean maximum temperatures were consistently higher in covered than uncovered plots. Maximum (day) temperatures were influenced more than minimum (night) temperatures. The highest mean air temperature and the greatest modification of air temperature occurred in the covered white-on-black polyethylene treatment.

Fruiting year (1990). Primocane emergence began 1 Apr. in the two polyethylene-covered plots. Primocanes in the handweeded, napropamide, and simazine-treated plots started emerging by 5 Apr. Primocanes in the untreated and straw-covered plots emerged on 11 Apr. Although most canes emerged in April and early May in all the plots, emergence of new canes in the straw-covered plots continued through July.

Raspberry plants in the straw-covered plots produced the longest primocanes (Table 3). The date of emergence appeared to have no effect on the eventual length of canes. The most important factor governing cane length was the growth rate of canes immediately after emergence. Canes of straw-mulched plants were already the longest by 11 May, even though they were the latest to emerge. The carry-over effects of poor establishment-year weed control were illustrated by the reduced cane length and overall vigor of plants in plots with unmanaged weed growth.

Certain establishment-year mulches in 1989 enhanced pro- duction in 1990 (Table 3). While cane density was highest in the straw-mulched plots, both the straw and black polyethylene led to significantly more primocanes than either simazine or napropamide. By the autumn of 1991, effects of weed control treatments were still evident, with straw-mulched plots having significantly more primocanes than all but the black polyethylene-covered plots.

Weed treatment influenced the percentage of canes that bore fruit (Table 3). Napropamide, simazine, and white-on-black polyethylene each led to the production of a higher percentage of fruiting canes than found for untreated, handweeded, or strawcovered plots. Yield per cane was highest in the previously weedy (untreated) plots, with little difference among the rest (Table 3).

Straw-mulched plants produced significantly higher fruit yield than plants in any other weed-management treatment (Table 3). Significant weed control $\times$ row cover interactions occurred. Plots with black polyethylene and row cover yielded more fruit than uncovered plots, but fruit yield was lower when strawmulched plots were covered.

The proportion of all fruit produced during the first half of the harvest season (early yield) was affected by establishmentyear weed control and row cover treatments (Table 3). Straw, black polyethylene, and white-on-black polyethylene each led to the production of a greater percentage of total fruit crop during the first half of the harvest season, relative to other treatments, although some of the differences were not significant.

Weed control had no consistent effect on fruit size until late in the harvest season. Fruit was smallest with the straw mulch during the last three harvest dates (data not shown). Fruit size during this period, however, was below the season's average in all treatments.

A major portion of the total number of graded canes were of the largest commercial classes, irrespective of weed treatment (Table 4). Straw-covered plots produced significantly more largediameter canes than any other treatment in 1990. Cane density had little or no effect on cane diameter. Effects of mulching treatments in 1989 were still measurable after the third growing season. Cane densities at the end of harvest in 1991 (Table 5) were similar to those in 1990 (Table 3).

\section{Discussion}

Weed competition has a negative effect on raspberry growth and productivity (Lawson and Wiseman, 1976); however, weed

Table 2. Effect of weed-control treatments on soil microenvironment during the planting year at three representative dates.

\begin{tabular}{|c|c|c|c|c|c|c|}
\hline \multirow[b]{3}{*}{ Treatment } & \multicolumn{4}{|c|}{$\begin{array}{c}\text { Soil moisture } \\
(\mathrm{kPa})\end{array}$} & \multirow{2}{*}{\multicolumn{2}{|c|}{$\begin{array}{c}\text { Soil temperature } \\
\left({ }^{\circ} \mathrm{C}\right)\end{array}$}} \\
\hline & \multicolumn{2}{|c|}{ July } & \multicolumn{2}{|c|}{ August } & & \\
\hline & - Rowcover & + Rowcover & Rowcover & + Rowcover & - Rowcover & + Rowcover \\
\hline Untreated & $90^{\mathrm{z}}$ & --- & 86 & --- & $23.1^{\mathrm{z}}$ & --- \\
\hline $\begin{array}{l}\text { Handweeded } \\
\text { Napropamide }\end{array}$ & $\begin{array}{l}70 \\
65\end{array}$ & $\begin{array}{l}36 \\
---\end{array}$ & $\begin{array}{l}65 \\
47\end{array}$ & $\begin{array}{l}71 \\
---\end{array}$ & $\begin{array}{l}24.0 \\
22.4\end{array}$ & $\begin{array}{c}27.8 \\
---\end{array}$ \\
\hline Simazine & 62 & --- & 50 & --- & 24.3 & -- \\
\hline $\begin{array}{l}\text { Black polyethylene } \\
\text { White-on-black }\end{array}$ & 14 & 9 & 23 & 12 & 26.1 & 26.3 \\
\hline polyethylene & 13 & 9 & 20 & 15 & 24.1 & 28.5 \\
\hline Straw & 11 & 10 & 15 & 11 & 19.5 & 22.7 \\
\hline LSD $(0.05)$ & 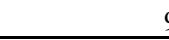 & 9 & & 23 & & \\
\hline
\end{tabular}

${ }^{2}$ Values are averaged over two fertilizer treatments of two replicates each for a total of four experimental units. 


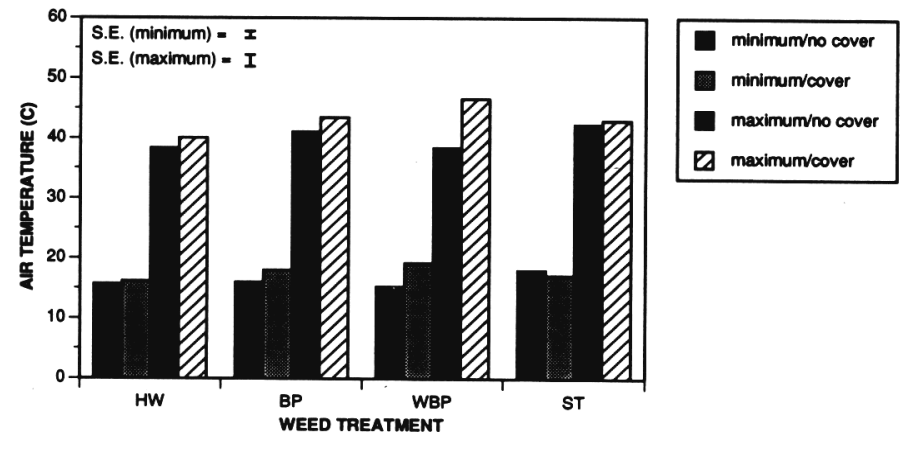

Fig. 3. Minimum and maximum mean air temperatures at soil level during the first growing season (1990) as influenced by weed control and row cover treatments. Each bar represents the mean of six readings. SE reported for both the seasonal minimum and maximum temperatures. Key to treatments: $\mathrm{HW}=$ handweeded, $\mathrm{BP}=$ black polyethylene, $\mathrm{WBP}=$ white-on-black polyethylene, and ST $=$ straw .

management practices developed for conventionally propagated raspberries may not be appropriate for succulent, tissue-cultured transplants. For example, MP raspberries are sensitive to cultivation and to standard herbicide programs initiated soon after planting (Meador, 1985; Mudge et al., 1987; Neal et al., 1990).

Mulches appear to be an attractive alternative to herbicides or cultivation for early season weed control in new plantings. Straw and polyethylene are relatively inexpensive and readily available. Methods exist to mechanically apply these mulches. They do not have a deleterious effect on soil structure, and they do not leave a potentially harmful residue in the soil. In addition, mulches conserve soil moisture that can aid in plant growth. Mulches are beneficial in established plantings (Childs, 1941; Clark, 1940; Darrow and Magness, 1938; Judkins, 1944), and our data show benefits for new MP plantings as well.

Mulches significantly modified soil moisture and temperature. In June, temperature differences among plots were as much as $5 \mathrm{C}$. By August, the largest difference was $3 \mathrm{C}$, and by October, soil temperatures were nearly identical in all plots. However, temperature was not related to performance. Plant growth was best in the coolest (straw mulch) and warmest (polyethylene mulch) plots, but soil moisture was positively associated with establishment-year cane growth (e.g., soil moisture tension in mid-July and final cane length, $r=0.85, P<0.001$, from Tables 1 and 2).

Weed management treatments that exacerbated soil moisture depletion (e.g., unmanaged weed growth) were associated with the poorest performance, even though drip irrigation was used to maintain soil water potential $<100 \mathrm{kPa}$ in the upper root zone. Treatments that allowed unimpeded evaporation from the soil surface also performed poorly (e.g., handweeding and herbicides). Mulches that posed a barrier to evaporation performed better (polyethylene mulches), and a mulch that posed a barrier to evaporation yet allowed rainfall to infiltrate (straw) performed the best. When an additional barrier to evaporation was placed over the plants (row covers), growth was again enhanced. The exception was the straw mulch where the row cover reduced plant growth, perhaps by providing supraoptimal moisture conditions. We did not measure soil oxygen status to determine if this was limiting growth in the covered, straw-mulched plots.

If temperature had been an important environmental variable influencing plant growth, then one would have expected the covered, straw-mulched plots to have performed better, and one would expect a significant correlation between temperature and plant growth. Instead, plant growth was correlated significantly with soil moisture during the establishment year.

Unmanaged weed growth appeared to reduce both moisture (Table 2) and $\mathrm{N}$ availability (Table 1 ) to the young raspberry plants, and it reduced plant growth. Although straw mulch increased leaf $\mathrm{K}$, initial soil tests $\left(270 \mathrm{~kg} \cdot \mathrm{ha}^{-1}\right)$ and foliar analysis indicated that $\mathrm{K}$ was not limiting. A similar pattern of growth and nutrient response was reported in apple (Malus domestica Borkh.) trees under analogous weed management systems (Merwin and Stiles, 1991).

MP raspberries apparently are sensitive to simazine herbicide (Neal et al., 1990). Although the physiological basis for this sensitivity is unknown, we measured a significant reduction in stomatal conductance in simazine-treated plants. Others also have observed stomatal closure in response to simazine in other crops (Shone and Wood, 1972; Sikka et al., 1964).

Fertilizer placement had no measurable effect on any of the variables, indicating that either placement method is acceptable. Our data suggest that mechanized transplanting units that band

Table 3. Effect of weed-control treatments on 2nd-year growth (1990) and yield of 'Heritage' raspberry. Percentage of early yield is the proportion of the total crop harvested during the first half of the harvest season.

\begin{tabular}{|c|c|c|c|c|c|c|c|c|}
\hline \multirow[b]{2}{*}{ Treatment } & \multirow{2}{*}{$\begin{array}{c}\text { Cane } \\
\text { length } \\
(\mathrm{cm})\end{array}$} & \multicolumn{2}{|c|}{$\begin{array}{c}\text { Cane } \\
\text { density } \\
\text { (no./0.5 m²) } \\
\end{array}$} & \multirow{2}{*}{$\begin{array}{c}\text { Fruiting } \\
\text { canes } \\
(\%)\end{array}$} & \multirow{2}{*}{$\begin{array}{c}\text { Yield } \\
\text { per cane } \\
(\mathrm{g})\end{array}$} & \multicolumn{2}{|c|}{$\begin{array}{c}\text { Yield } \\
(\mathrm{kg} / 4.5 \mathrm{~m})\end{array}$} & \multirow{2}{*}{$\begin{array}{c}\text { Early } \\
\text { yield } \\
(\%)\end{array}$} \\
\hline & & May & October & & & -Rowcover & + Rowcover & \\
\hline Untreated & $114^{z}$ & $9^{z}$ & 12 & $79^{z}$ & $475^{z}$ & $5.63^{y}$ & $\ldots$ & $27^{z}$ \\
\hline Handweeded & 132 & 31 & 29 & 83 & 262 & 6.49 & 7.96 & 31 \\
\hline Napropamide & 125 & 23 & 27 & 93 & 226 & 5.69 & --. & 28 \\
\hline Simazine & 129 & 30 & 28 & 91 & 245 & 6.66 & $\ldots$ & 27 \\
\hline Black polyethylene & 127 & 41 & 37 & 87 & 205 & 6.48 & 8.34 & 36 \\
\hline \multicolumn{9}{|c|}{ White-on-black } \\
\hline polyethylene & 128 & 32 & 33 & 90 & 225 & 6.92 & 7.16 & 34 \\
\hline Straw & 139 & 75 & 51 & 82 & 202 & 11.11 & 9.32 & 36 \\
\hline $\operatorname{LSD}(0.05)$ & 10 & 9 & 6 & 8 & 60 & \multicolumn{2}{|c|}{1.85} & 6 \\
\hline
\end{tabular}

${ }^{2}$ Values for handweeded and mulched plots are averaged over two fertilizer and row cover treatments of three replicates each for a total of 12 experimental units. Herbicide and control treatments represent six experimental units.

yValues are averaged over two fertilizer treatments of three replicates each for a total of six experimental units. 
Table 4. Effect of weed-control treatments on the distribution of cane diameter within a $0.5 \mathrm{~m}^{2}$ area in 'Heritage' raspberry at the end of the 2nd year (1990).

\begin{tabular}{|c|c|c|c|c|c|c|}
\hline \multirow[b]{2}{*}{$\mathrm{Tr}$ e a $\mathrm{tm} \mathrm{e} \mathrm{nt}$} & \multicolumn{4}{|c|}{ Cane diam class (no.) } & \multirow{2}{*}{$\begin{array}{l}\text { Total canes } \\
\text { graded } \\
\text { (no.) }\end{array}$} & \multirow{2}{*}{$\begin{array}{c}\text { Canes } \geq 6 \mathrm{~mm} \\
\text { in diam } \\
\%\end{array}$} \\
\hline & $\geq 9 \mathrm{~mm}$ & $6-8 \mathrm{~mm}$ & $3-5 \mathrm{~mm}$ & $<3 \mathrm{~mm}$ & & \\
\hline Untreated & $4.4^{2}$ & 4.4 & 1.2 & 0 & 10.0 & 88 \\
\hline Handweeded & 8.7 & 9.7 & 42 & 0.2 & 22.7 & 81 \\
\hline Napropamide & 7.7 & 8.8 & 3.3 & 03 & 20.2 & 82 \\
\hline Simazine & 6.7 & 11.3 & 3.7 & 0.2 & 22.0 & 82 \\
\hline Black polyethylene & 7.7 & 16.1 & 4.8 & 0.5 & 29.0 & 82 \\
\hline $\begin{array}{l}\text { White-on-black } \\
\text { polyethylene }\end{array}$ & 6.5 & 13.9 & 4.2 & 0.7 & 25.4 & 80 \\
\hline Straw & 10.5 & 21.8 & 8.4 & 2.3 & 40.6 & 80 \\
\hline LSD $(0.05)$ & 2.9 & 5.0 & 2.8 & 0.9 & 6.1 & \\
\hline
\end{tabular}

${ }^{2}$ Values for handweeded and mulched plots are averaged over two fertilizer and row cover treatments of three replicates each for a total of 12 experimental units. Control and herbicide treatment means are averaged over two fertilizer treatments of three replicates each for a total of six experimental units.

Table 5. Effect of weed-control treatments on 'Heritage' raspberry primocane density after the third growing season (1991).

\begin{tabular}{lc}
\hline \hline Treatment & Cane density $\left(\mathrm{no.} / 0.5 \mathrm{~m}^{2}\right)$ \\
\hline Untreated & $19.7^{2}$ \\
Handweeded & 25.3 \\
Napropamide & 25.3 \\
Simazine & 21.2 \\
Black polyethylene & 27.7 \\
White-on-black polyethylene & 25.8 \\
Straw & 31.7 \\
LSD (0.05) & 5.0 \\
\hline
\end{tabular}

${ }^{2}$ Values for handweeded and mulched plots are averaged over two fertilizer and row cover treatments of three replicates each for a total of 12 experimental units. Control and herbicide treatment means are averaged over two fertilizer treatments of three replicates each for a total of six experimental units.

fertilizer under the row, while simultaneously laying plastic mulch and planting, should be acceptable for MP raspberries.

Carryover effects from establishment-year treatments continued to influence plant growth during the second and third growing season, even though the mulches and row covers were removed before spring growth in the second year. In the second growing season, primocanes in straw-mulched plots emerged last, but they grew faster than primocanes in other treatments, becoming taller by the end of the season. Plants in mulched plots not only produced higher yields than those in other treatments, but matured a higher proportion of the crop earlier. Cane density was the yield component responsible for the higher productivity, as yield/cane was similar among all the treatments, except where no weed control was practiced. Differences in cane density due to planting year treatments were maintained throughout the third growing season.

Some growers thin canes to accelerate crop maturity in primocane-fruiting raspberries. Our data suggest that this practice will lower yields with no effect on maturity. In fact, the earliest production occurred where cane density was highest.

To summarize, the mulched plots controlled weeds and increased soil moisture status for the MP plants, and this resulted in improved performance relative to herbicide use or handweeding for weed control. We hypothesize that the higher moisture under straw allowed the MP plants to develop a stronger root system during establishment. Because of a larger root system, growth was greater during the first year, primocanes were more numerous, and growth was accelerated the following year. Rooting may also have been deeper in mulched plots, as suggested by the observation that primocane emergence was later.

Row covers appeared to benefit MP plants by reducing moisture loss. Row covers on newly established MP plants also may be beneficial in windy climates or where late frosts are common (A. Otterbacher, personal communication).

Mulching newly planted MP raspberries offers an attractive, environmentally friendly alternative to herbicides or cultivation for weed control in young plantings. Benefits also occur at the physiological level and are expressed in subsequent years as greater cane density, better cane growth, higher productivity, and accelerated ripening. However, mulching newly planted, MP raspberries should be tested under a wider range of conditions to determine if similar results can be expected by growers in most situations.

\section{Literature Cited}

Childs, W.H. 1941. Production, berry size and growth of red raspberries as influenced by mulching. Proc. Amer. Soc. Hort. Sci. 38:405-409.

Clark, J.H. 1940. The effects of mulching red raspberries on growth and production. Proc. Amer. Soc. Hort. Sci. 37:604-608.

Darrow, G.M. and J.R. Magness. 1938. Investigations on mulching red raspberries. Proc. Amer. Soc. Hort. Sci. 36:481-484.

Judkins, W.P. 1944. The effect of straw mulch, cultivation, and nitrogen fertilizer on the growth and yield of 'Latham' raspberries. Ohio Agr. Expt. Sta. Bimonthly Bul. 29:154-484.

Lawson, H.M. and J.S. Wiseman. 1974. Effect of weeds and herbicides in young raspberry plantations. Proc. Brit. Weed Control. Conf. 12:683-690.

Lawson, H.W. and J.S. Wiseman. 1976. Weed competition in spring planted raspberries. Weed Res. 16:155-162.

Meador, D.B. 1985. Impact of herbicides on field-planted, succulent, tissue-culture propagated, red raspberry plants. HortScience 20:48. (Abstr.)

Merwin, LA. and W.C. Stiles. 1991. Alternative groundcover management systems affect orchard soil fertility and apple leaf nutrient content. HortScience 26:168. (Abstr.)

Mudge, K.W., C.A. Borgman, J.C. Neal, and H.A. Weller. 1987. Present limitations and future prospects for commercial micropropagation of small fruits. Proc. Intl. Plant Prop. Soc. 36:538-543.

Neal, J.C., M.P. Pritts, and A.F. Senesac. 1990. Evaluation of preemergent herbicide phytotoxicity to tissue culture-propagated 'Heritage' red raspberry. J. Amer. Soc. Hort. Sci. 115:416-422.

Pollard, J.E. and C.M. Cundari. 1988. Over-wintering strawberry plants 
under rowcovers increases fruit production. HortScience 23:332333.

Pritts, M.P. and D. Handley (eds.). 1989. Bramble Production Guide. Northeast Reg. Agr. Eng. Serv. Publ. 35, Ithaca, N.Y.

Pritts, M., E. Hanson, J. Fiola, and M.J. Kelly. 1992. Row covers accelerate fruiting and increase productivity in primocane-fruiting red raspberries. HortTechnology (2:46-51.).

Pritts, M.P., K.A. Worden, and M. Eames-Sheavly. 1989. Rowcover material and time of application and removal affect ripening and yield of strawberries. J. Amer. Soc. Hort. Sci. 114:531-536.
Randall, G.W. 1984. Efficiency of fertilizer nitrogen use as related to application methods, p. 521-533. In: R.D. Hauck (ed.). Nitrogen in crop production. Amer. Soc. Agron., Madison, Wis.

Shone, M.G.T. and A.V. Wood. 1972. Factors affecting absorption and translocation of simazine by barley. J. Expt. Bot. 23:141-151. Sikka, H.C., D.E. Davis, and H.H. Funderburk. 1964. The effect of various types of herbicides on transpiration rate of soybean (Glycine max Merr.). Proc. Southern Weed Conf. 17:340-350.

Voth, V. and R.S. Bringhurst. 1990. Culture and physiological manipulation of California strawberries. HortScience 25:889-894. 